Etikonomi

Volume 15 (1), April 2016

P-ISSN: 1412-8969; E-ISSN: 2461-0771

Page 1 - 18

\title{
THE GO-PUBLIC POLICY AND ITS IMPACT TO THE INDONESIAN ISLAMIC BANKING SOUNDNESS
}

\author{
Aini Masruroh, Hasbi Siraj \\ UIN Syarif Hidayatullah Jakarta \\ aini.masruroh@uinjkt.ac.id, hasbi.siraj@gmail.com
}

\begin{abstract}
.
The needed of big fund inspired the companies to sell a part of its shares in the capital market. One of methods that used is to be a public company (Go-Public). However, for Islamic banking to be a public company is not main choice. At present, Islamic banking that was listing its shares in Indonesian Stock Exchange is one Islamic banking only. In this research described the comparison financial soundness of Islamic banking pre-Go-Public with postGo-Public. The used of the analysis was the analysis of financial ratios of components contained in RBBR (Risk-based Bank Rating). Comparing between a financial soundness of Islamic banking pre go-public and post go-public used comparison test Paired-sample t test. The financial soundness condition of Islamic banking pre- and post-Go-Public overall changed to a better level. However, based on the result of further tests, showed that GoPublic policy only influenced to capital factor.
\end{abstract}

Keywords: Islamic Banking; Go-Public; Risk-based Bank Rating

\begin{abstract}
Abstrak.
Kebutuhan dana yang besar menginspirasi perusahaan menjual sebagian sahamnya di Pasar Modal. Salah satu cara yang digunakan ialah menjadi perusahaan publik (Go-Public). Namun, bagi perbankan syariah menjadi perusahaan publik bukan pilihan yang utama. Saat ini bank syariah yang telah mencatatkan sahamnya di Bursa Efek Indonesia hanya satu bank syariah. Pada penelitian ini diuraikan perbandingan kesehatan keuangan bank syariah antara sebelum Go-Public dengan sesudah Go-Public. Analisis yang digunakan adalah dengan analisis komponen rasio keuangan yang terdapat pada RBBR (risk-based bank rating). Untuk membandingkan antara kesehatan keuangan bank syariah pra Go-Public dengan pasca Go-Public digunakan uji beda paired-sample $t$ test. Kondisi kesehatan keuangan bank syariah sebelum dan sesudah Go-Public secara keseluruhan mengalami perubahan ke tingkat yang lebih baik. Namun, berdasarkan hasil uji lanjutan menunjukan bahwa kebijakan Go-Public hanya berpengaruh pada faktor modal.
\end{abstract}

Kata Kunci: Bank Syariah; Go-Public; Risk-based Bank Rating

Received: December 15, 2015; Revised: February 2, 2016; Approved: February 20, 2016 
The Go-Public Policy and Its Impact to the Indonesian Islamic Banking Soundness Aini Masruroh, Hasbi Siraj

\section{INTRODUCTION}

Islamic Banking has become an enthusiast of financial institutions in Indonesia. It approved from various achievements since it first operated in 1992. The achievement that is often published is an increase of market share and asset growth as well as numerous other achievements. However, the reality of Islamic banking in 2014 faces the challenges of slowing growth.

In some Indonesia regions, there is information that indicates a weakness of Islamic banking. For instance, it is occurred in Banten. The attractiveness of Islamic banking is unable to compete a conventional banking which increases from $7.52 \%$ to $7.93 \%$. This condition affects to asset growth. It is showed by decline of asset becoming $4.15 \%$ in 2014 -second quarter comparing to $8.21 \%$ in the same quarter in last year. Apparently, the majority of the Indonesian population, which is Moslem, does not guarantee the movement of Islamic financial quickly. It is showed by the point of market share (below 5\%). Moreover, this figure decreased significantly from $3.70 \%$ in 2013 to $4.80 \%$ in 2014 .

\section{Figure 1. Islamic Banking Market Share}

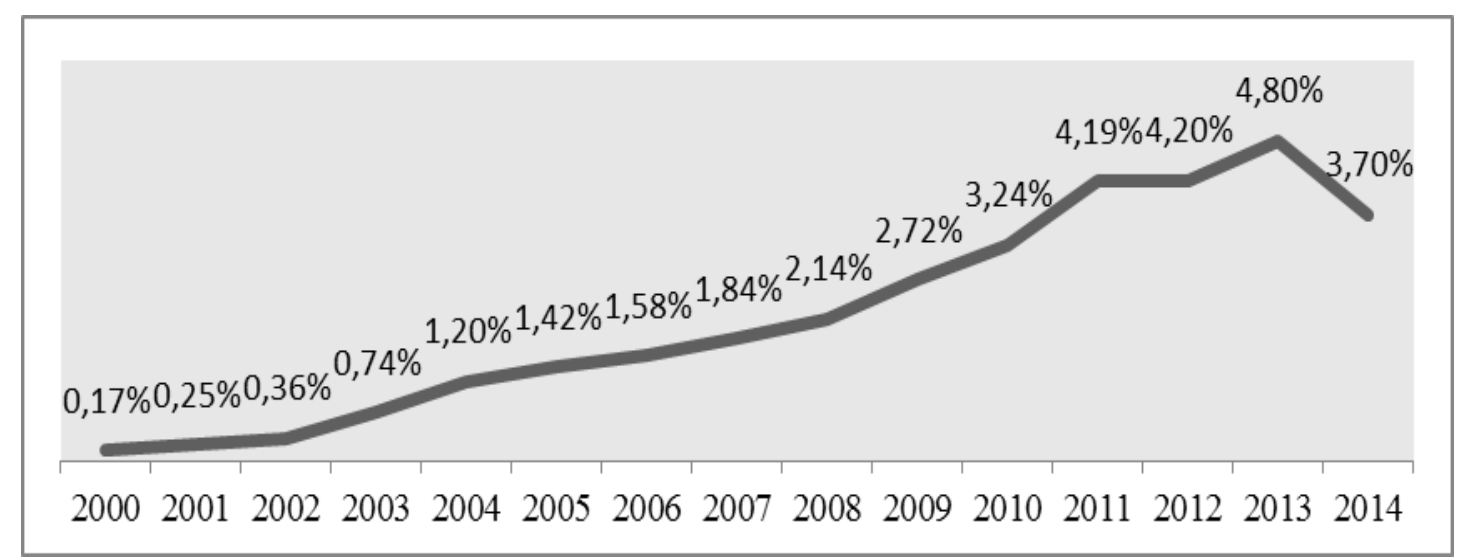

Source: Bank of Indonesia and Financial Service Authority

Besides, the total assets of National Islamic banking nationally in June 2015 reached Rp272.6 trillion only. This number is much smaller than the total of national banking assets as a whole (Rp.5933.2 trillion). In Herman (2014) Kariastanto said that there are at least three possible reasons why the market share of Islamic banks in Indonesia is very low. First, it is about the lack of Islamic bank Moslem awareness. Second, infrastructure and quality of Islamic banks is 
significantly less than conventional banking. Third, conventional banks have nontechnical advantages compared to Islamic banks. Looking to the problems that faced by Islamic banking, it needs a development strategy to cover all aspects to be resolved. Financial Services Authority (OJK)'s policy, provides a variety of strategies in the development of Islamic finance in Indonesia, especially Islamic banking.

The roadmap of Islamic Banking in Indonesia 2015 - 2019 issued by the $\mathrm{OJK}$, is composed of a vision of the development of national Islamic banking namely "to enable Islamic banking which contributes significantly to sustainable economic growth, equitable development and stability of the financial system as well as the highly competitive". Then, the strategies outlined in the roadmap are crucial strategy existence. The strategy is to strengthen its capital and business scale and improve the efficiency of Islamic banking. The essential of it can simply be explained that strengthen of capital and efficiency of business scale becomes a basis for Islamic banking that able to resolve the problems encountered. This argument is quite obvious, because if this strategy is not realized, then it is very likely that a variety of other strategies such as upgrading infrastructure, improving the quality of technology, product innovation, improving the quality of human resources and a variety of other strategies that require huge funds cannot be implemented.

Islamic banking development strategy that focuses on providing freedom of capital increase related to the way in which to increase the capital. Islamic banking can optimize public funds that are so large in number in the capital market by issuing securities. One of the alternatives that can be taken is to become a public company (Go-Public).

In early 2014, precisely on January 15, 2014, Islamic Panin Bank became the first Islamic bank and the only one to register his name in the Indonesia Stock Exchange. Islamic Panin Bank, which incidentally is younger than the Bank of Muamalat Indonesia and Bank of Sharia Mandiri, has conducted an IPO (Initial Public Offering / IPO). It is needed to be reviewed in depth regarding Islamic Panin Bank policy that has been made. Moreover, the policy is taken amid a state where Islamic banks have yet to do an IPO. 
The Go-Public Policy and Its Impact to the Indonesian Islamic Banking Soundness Aini Masruroh, Hasbi Siraj

Islamic Panin Bank management policy to Go-Public is a business decision that was selected after taking into accounts the benefits and consequences. There are so many benefits that can be obtained when it becomes a company Go-Public, but there are some consequences to be considered. The consequences faced by companies who do not Go-Public policy of the benefits that will be achieved. In addition, the policy is expected to Go-Public would be able to improve the quality of financial soundness that Islamic banks have often said to lack the capital to expand more massive.

\section{METHOD}

This research's scope is Islamic Panin Bank. It is described the soundness data of Islamic Panin Bank from 2010 to 2014. However, this study focused on the effects caused by the policy of going public on the financial soundness of Islamic Panin Bank. The analysis used by comparing the soundness condition of banks prego-Public pre and post- go-public. Risk Based Bank Rating (RBBR) method is used in this research. In RBBR method, there are four factors that accounted for the Risk Profile, Good Corporate Governance, Earnings and Capital (RGEC). The variables are used in this study is ROA, NOM and CAR contained in earnings and capital factors. Furthermore, to determine whether or not to Go-Public influence on ROA, NOM and CAR analysis that was used to test the average difference paired sample t-test.

The sample in this study uses purposive sampling technique. Purposive sampling is a sampling technique that is based on defined characteristics to the elements tailored to the target population of interest or research problems. The quantitative data used are derived from the financial statements of Islamic Panin Bank. The financial statements used are the quarterly financial statements of the period March 2013 - December 2014 period in 2013 were financial statements prior to going public and the period in 2014 was a financial report after going public.

This study aimed to compare the financial soundness of Islamic Panin Bank Go-Public pre and post Go-Public. Soundness banks are explicitly represented by financial ratios contained in earnings and capital factors. Although it does not deny 
that in the end the banks will be assessed their soundness as well as by other factors. However, the information that the public generally consumed is in the form of financial ratios. As in this study, the financial ratios in this analysis are ROA, NOM and CAR.

The data that have been collected and counted associated with the overall objective of this study then the data have tested using two testpaired samples (Paired-sample $t$ test). Paired-sample $t$ test was used to determine whether or not the average difference the two groups of samples are paired (associated). It means a sample with two different treatments. The first sample is prior to Islamic Panin Bank Go-Public and a second sample after Islamic Panin Bank Go-Public so that its output will be seen whether or not the difference in the average of the bank's financial performance Islamic Panin Bank.

\section{DISCUSSION}

The condition of Islamic Panin Bank financial soundness Pre Go-Public

Financial Information on the company financial report/bank can provide the financial soundness condition. It can also assess the performance of the corresponding bank management so that is expected to maintain the transparency to the public. The measurement of the condition of the financial soundness of Islamic Panin Bank is based on the Bank of Indonesia Regulation No.13/1/PBI/2011 namely with an approach based on risk (risk-based bank rating). In the regulation has been explained how the bank assess their soundness by assessing several factors including risk profile, good corporate governance, earning and capital. In addition to the factors, also see various others financial indicators commonly used including total assets, third party funds and net profit. 
The Go-Public Policy and Its Impact to the Indonesian Islamic Banking Soundness Aini Masruroh, Hasbi Siraj

Table 2. Stages of the risk profile

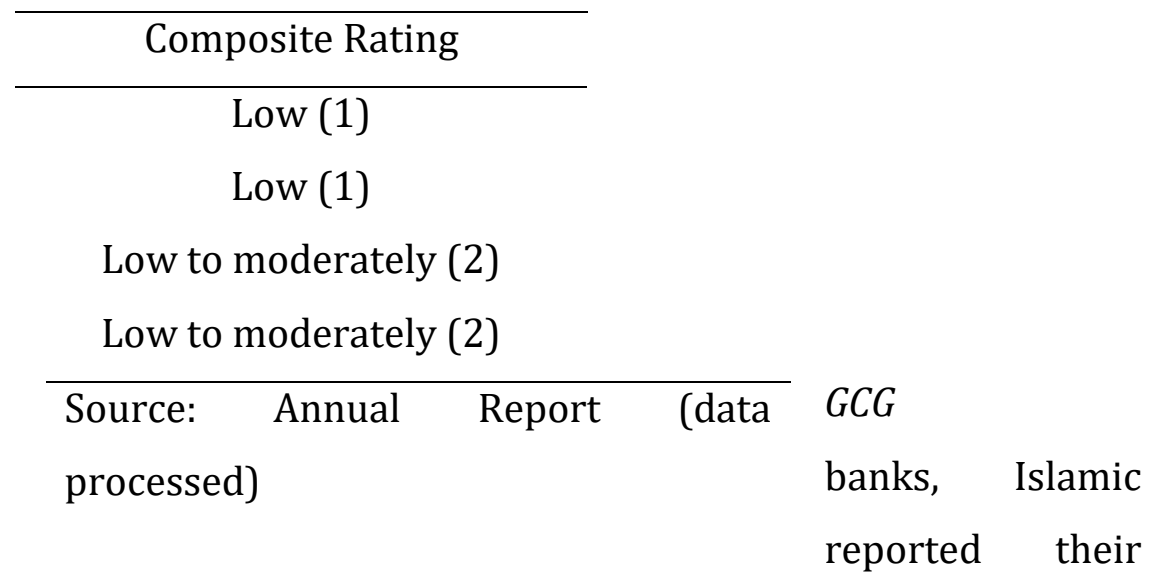

soundness level based on PBI about risk-based bank rating. On the risk factor profile from 2010 to 2013 respectively is always in a secure rating from the possibility of a big risk, low, and low to moderately. It means between 2010 and 2011 potential losses faced by the bank from the risks inherent composites is considered very low and the quality of the implementation of risk management in a composite is very inadequate. Although there is a minor weakness, the weakness can be ignored. Then in the next two years i.e. 2012 and 2013, the possibility of loss is still considered low and the quality of the implementation of adequate risk management. However, the minor weakness must be paid attention from the management. The following is the table from the stages of the risk profile from 2010 to 2013.

Table 3. The Results of The Self-Assessment of GCG

\begin{tabular}{ccl}
\hline The Year & The Value & Rated \\
\hline 2010 & 2.2 & Good \\
2011 & 1.95 & Good \\
2012 & 1.35 & Very Good \\
2013 & 1.35 & Very Good \\
\hline
\end{tabular}

Source: GCG Implementation Reports (data processed)

Assessment of factors GCG (Good Corporate Governance) on the Islamic Panin Bank also shows that the bank management has been doing the implementation of GCG between 2010 and 2011. This means that in general when 
there is a weakness in the implementation of GCG, and then the weakness can be completed with normal action. Then the next two years i.e. 2012 and 2013 an increasing the stages of GCG becomes very good.

Figure 2. The fluctuations in Net Profit Islamic Panin Bank

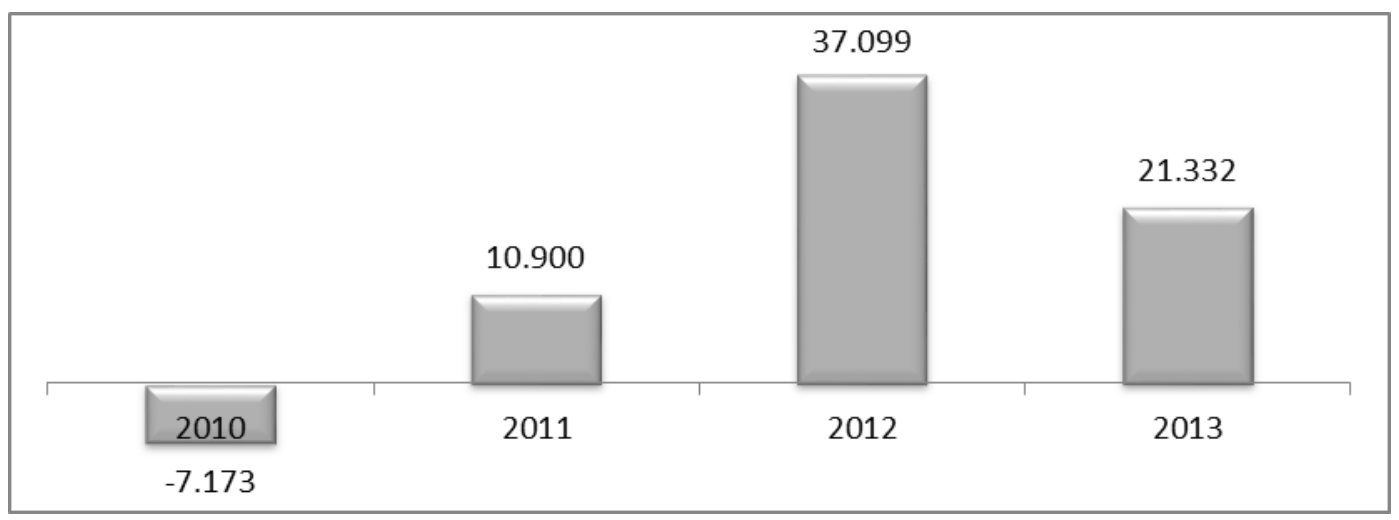

Source: Annual Report Islamic Panin Bank (data processed)

\section{Earning}

On the factor earning, many financial ratios can be measured. However, it is undeniable that the size of the profitability that used is ROA. Before analysing an ROA, there are indicators that also need to be seen on the Islamic Panin Bank, i.e. net profit and BOPO (Operational Expenses and Operational Income) that has been achieved in the bank.

Figure 3. The BOPO Fluctuation of Islamic Panin Bank

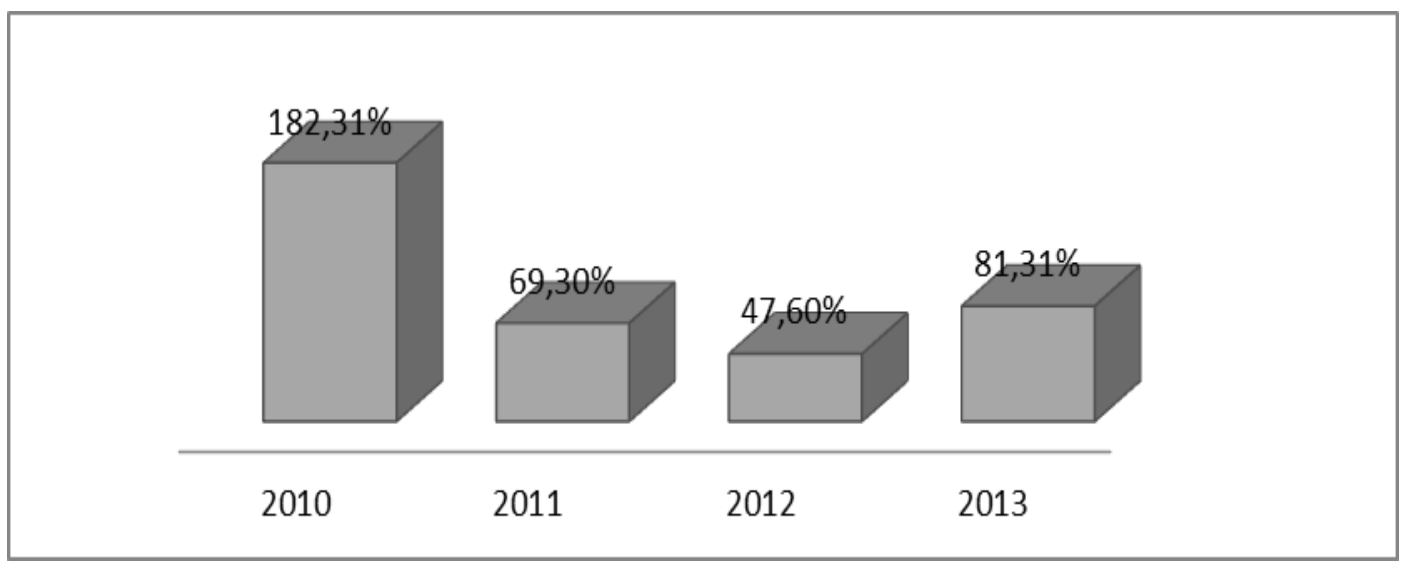

Source: Annual Report Islamic Panin Bank (data processed)

From 2010 to 2013, fluctuations happened in high on the net profit of Islamic Panin Bank. Even in 2010, bank losses of Rp7.2 billion. The loss was caused 
The Go-Public Policy and Its Impact to the Indonesian Islamic Banking Soundness Aini Masruroh, Hasbi Siraj

by the high of operational costs are used during 2010. This is shown by the high figure of BOPO that reach $182.31 \%$. That means that the management is not capable to reduce the operational costs. In the next year, the bank is able to improve its performance and become more efficient until finally records a profit Rp37 billion with BOPO 47.6\% in 2012. Although the profit declined in 2013 to Rp21 billion then it caused the increasing of operational budget (BOPO 81.31\%).

Between 2010 and 2013, Islamic Panin Bank experienced fluctuations in its performance reviewed from ROA. The average ROA was 1.01\% per year; bank capability to produce profit is questioned. Moreover, the average number is located under the specified standards of Bank Indonesia i.e. 1.25\%. However, the average number did not necessarily mean that the bank is not able to produce the same profit once. It was proven that in 2012 Panin Bank ROA was 3.48\%.

Figure 4. The ROA Fluctuations of Islamic Panin Bank

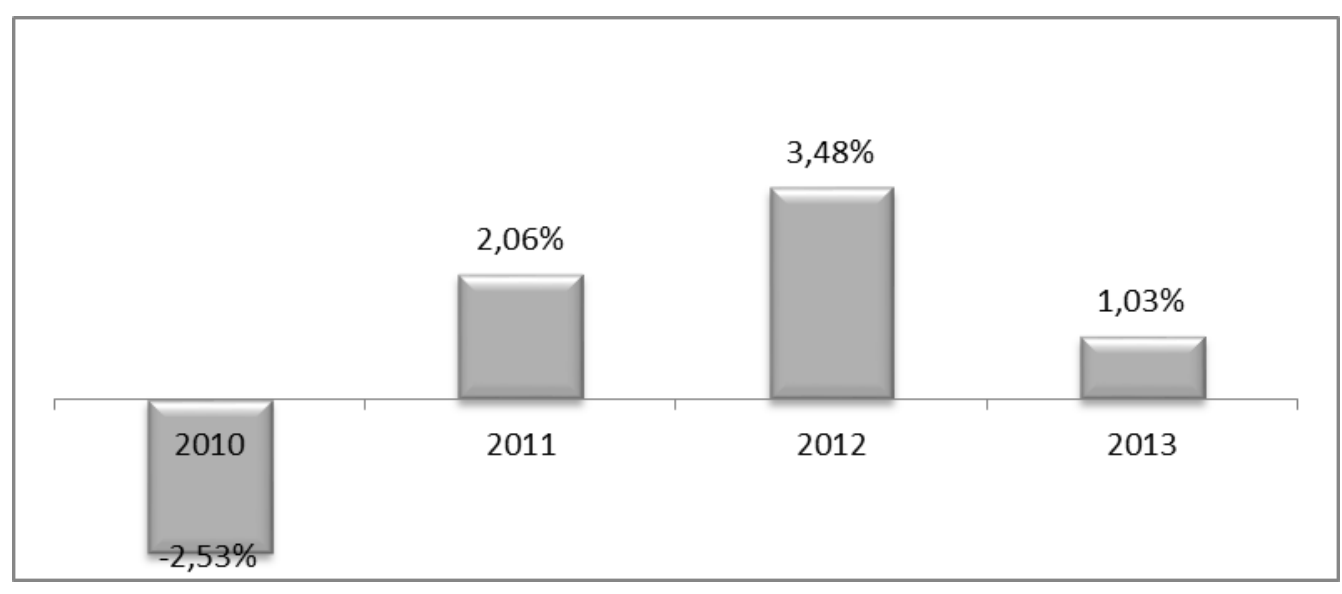

Source: Annual Report Islamic Panin Bank (data processed)

\section{Capital}

The last factor that was considered to see the soundness of the bank is a capital. From this factors will be known the quality and the bank owns the adequacy of the capital expenditure. The ratio is generally seen on earning factor is the CAR. CAR Islamic Panin Bank period of 2010 - 2013 have by an average of $42.48 \%$, this number far exceeded the minimum restrictions CAR that required by the Bank of Indonesia is 8 percent from ATMR. This showed that the Islamic Panin Bank able to maintain adequate capital and the bank management are able to identify, measure, monitor and control the risk that arise that can affect the 
amount of capital. The following table and graphs showed the Islamic Panin Bank CAR from 2010 to 2013.

Table 4

CAR Islamic Panin Bank

\begin{tabular}{cc}
\hline The Year & CAR \\
\hline 2010 & $54.81 \%$ \\
2011 & $61.98 \%$ \\
2012 & $32.30 \%$ \\
2013 & $20.83 \%$ \\
The average & $42.48 \%$ \\
\hline Source: Annual & Report (data \\
processed)
\end{tabular}

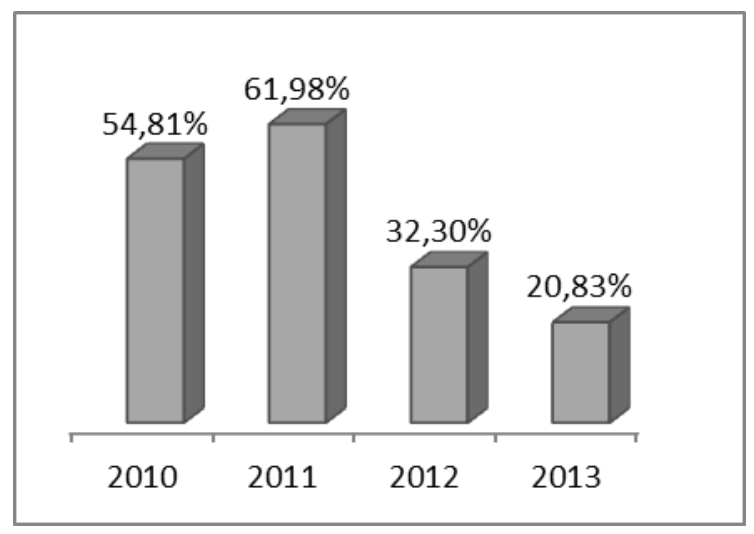

Figure 4. The fluctuations in CAR Islamic Panin Bank

In addition, the factors that were found in the method of risk-based bank rating are also some other financial indicators that usually seen including total assets and collecting funds from the third party. Islamic Panin Bank posted a very great asset on the period of 2010 - 2013. It was equal to $783.5 \%$, representing the increasing of Islamic Panin Bank total assets each year in this period. This increasing showed the impressive of management performance. It was recorded Islamic Panin Bank total assets per December 2013 reached Rp4.05 trillion.

Figure 6. Total assets of Islamic Panin Bank

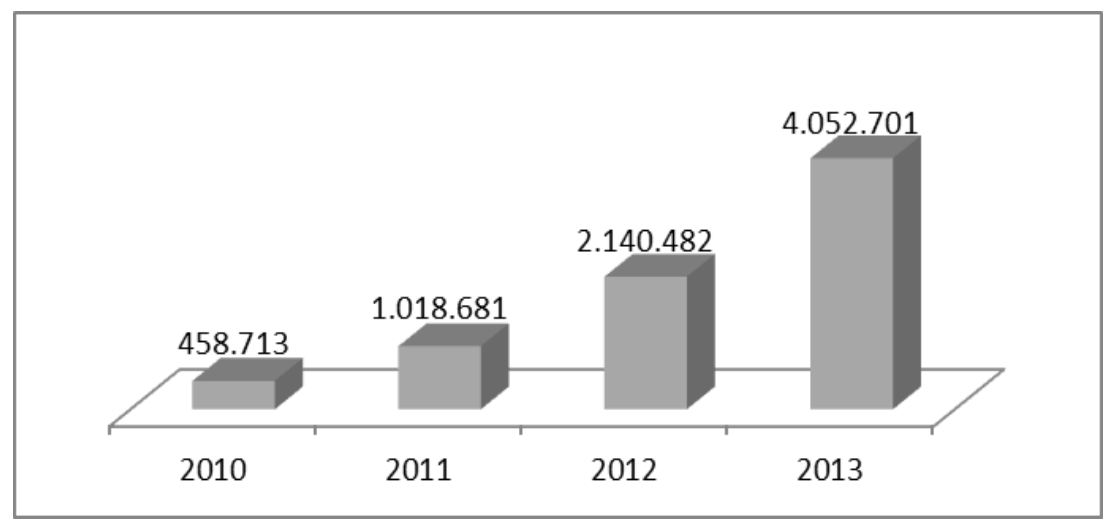

Source: Annual Report Islamic Panin Bank (data processed) 
The Go-Public Policy and Its Impact to the Indonesian Islamic Banking Soundness Aini Masruroh, Hasbi Siraj

In the same period was recorded as well third party funds that have successfully gathered. Third party funds from 2010 were Rp309 billion becoming Rp2.87 trillion in 2013 or increase 826\%. Average earnings each year also showed a very large figure, it reached $120 \%$ per year.

Figure 7. Third party fund Islamic Panin Bank

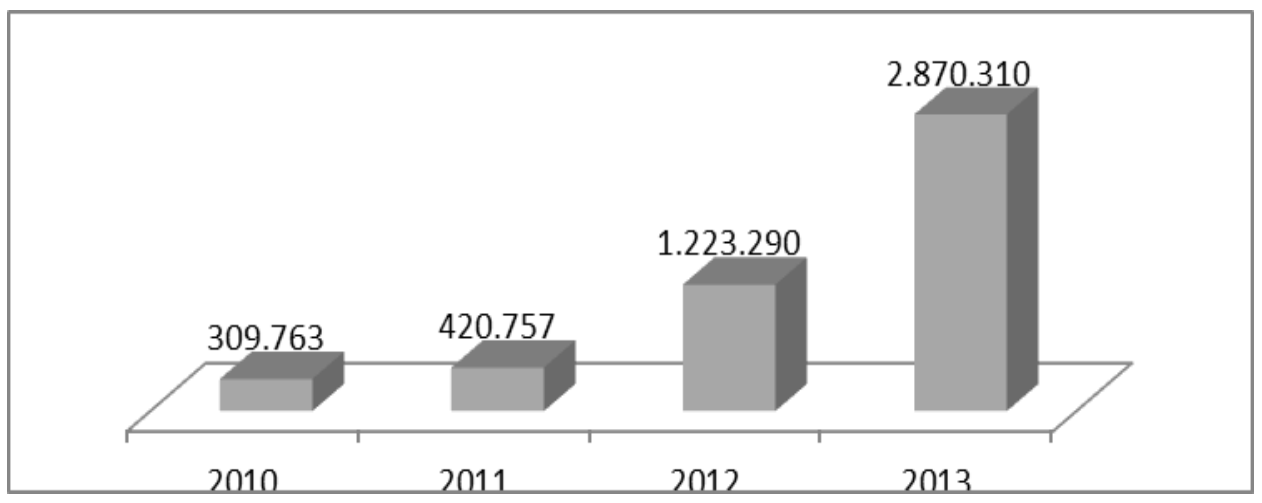

Source: Annual Report Islamic Panin Bank (data processed)

Overall, Islamic Panin Bank financial condition from 2010 to 2013 had increased from the amount of its assets, which increased rapidly until the collecting of third party funds. On the other side, there are several indicators that still needed to revamp. Financial Condition became the gate of the success when the IPO in the next year (2014).

Soundness Conditions of Islamic Panin Bank post Go-Public

Islamic Panin Bank officially noted in Indonesia Stock Exchange (BEI) on 15 January 2014. Islamic Panin Bank became first Islamic banks to do an initial public offering (IPO) in Indonesia. In addition, Islamic Panin Bank also became the first company recorded themselves in the stock in 2014.

The offered shares of Islamic Panin Bank in general offered 4.750.000.000 shares. Islamic Panin Bank held Employee Stock Allocation Program (Employee Stock Allocation or "ESA") by allocating 475.000 .000 shares or $10 \%$ from the number of shares offered in a Public Offering. The number of all the shares was recorded on the BEI (9.643.000.000 shares) or 99 percent of all capital placed and paid in full. This is in accordance with the Government Regulation No.29 1999 about Purchasing General Bank shares, where 1 percent of all the shares of the company are not recorded and owned by PT Bank Panin Tbk. 
The fund results from a public offering was Rp475 billion and reduced costs of securities emission, $80 \%$ used as working capital of the company to strengthen the structure of the long-term funding in order to support the expansion of the financing and around 20 percent to the development of the network includes the infrastructure of the company.

\section{Capital}

The first thing and definitely changed due to Go-Public policy was the transmission of some shares of Islamic Panin Bank. Recorded at the end of 2013, almost 100 percent owned by PT Bank Panin Tbk and only $0.000964 \%$ shares that belonged to the other party. After Go-Public ownership, Islamic Panin Bank only remaining of $52.11 \%$ despite a shareholder of a handler (PSP). Now some $24.71 \%$ other stocks owned by Dubai Islamic Bank and the rest of $23.17 \%$ owned by the community that spread to various parties but the amount of ownership of each his owner less than $5 \%$.

\section{Table 5}

Shareholders Pre Go-Public and Post Go-Public

\begin{tabular}{rlcccc}
\hline No & $\begin{array}{l}\text { Shareholders } \\
\text { Name }\end{array}$ & $\begin{array}{c}\text { Shares } \\
\text { Number }\end{array}$ & $(\%)$ & $\begin{array}{c}\text { Shares } \\
\text { Number }\end{array}$ & (\%) \\
\hline 1 & $\begin{array}{l}\text { PT Bank } \\
\text { Panin Tbk } \\
\text { Ahmad }\end{array}$ & $4,999,951,790$ & 99.99904 & $5,119,951,790$ & 52.11 \\
2 & $\begin{array}{l}\text { Hidayat } \\
\text { Dubai Islamic } \\
\text { Bank }\end{array}$ & - & 0.000964 & - & - \\
& $\begin{array}{l}\text { The } \\
\text { Community }\end{array}$ & - & - & $2,427,750,000$ & 24.71 \\
Total Shares & $5,000,000,000$ & 100 & $9,824,734,100$ & 100 \\
\hline
\end{tabular}

Source: Annual Reports and Prospectus Islamic Panin Bank (data processed)

From the side of the capital expenditure, total equity Islamic Panin Bank in year 2014 increased significantly from $\mathrm{Rp} 525$ billion to $\mathrm{Rp} 1.07$ trillion or to $104 \%$. And the CAR that was recorded at the end of the year 2014 is $25,69 \%$. Capital Adequacy is a strong basis for business development through increased distribution of financing in the future. 
The Go-Public Policy and Its Impact to the Indonesian Islamic Banking Soundness Aini Masruroh, Hasbi Siraj

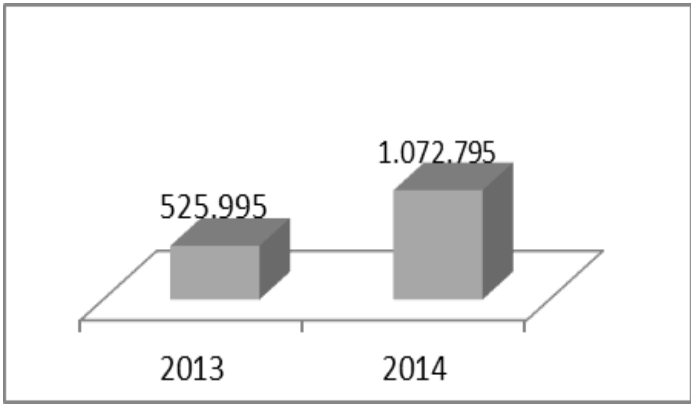

Source: Annual Report

(data processed)

Figure 8. Islamic Panin Bank Total Equity

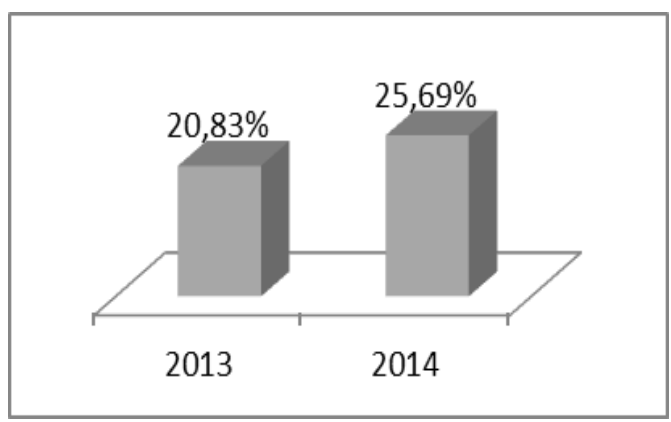

Source: Annual Report

(data processed)

Figure 9. Islamic Panin Bank CAR Earning

At the end of 2014, Islamic Panin Bank posted a net profit was Rp70.9 billion. It increased significantly compared to the record at the end of 2013 worth Rp21.3 billion. The achievement was supported by the performance of the bank management that both reflected through increased distribution of financing with the quality is maintained at a soundness level. In addition, the achievement was also supported by more efficient of Islamic Panin Bank operating throughout 2014. It was noted that efficiency ratio (BOPO) from the previous year 2013 which reached $81.31 \%$ became $68.47 \%$ by the end of 2014 .

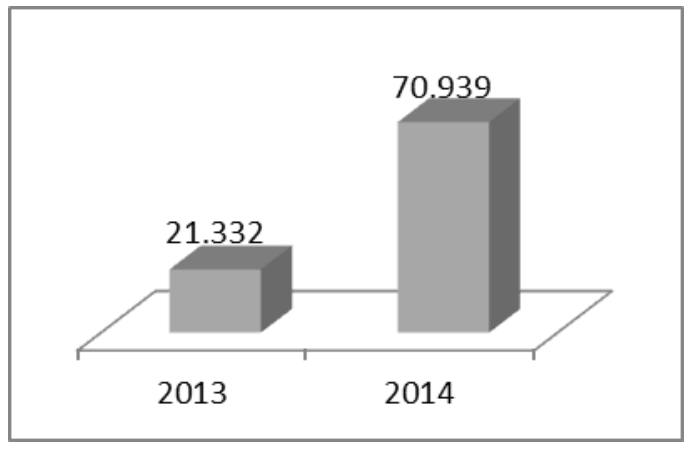

Source: Annual Report (data processed)

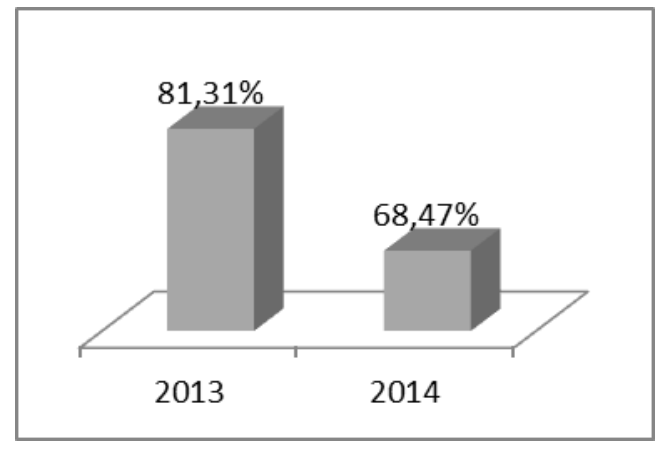

Source: Annual Report (data processed) Figure 11. Islamic Panin Bank BOPO

According to profitability, accomplishment was achieved by Islamic Panin Bank in 2014 also experienced a significant increase comparing to 2013. This was showed by ROA ratio in 2013 did not reach the specified standards of Bank Indonesia i.e. 1.25\% and Islamic Panin Bank reached 1.03\%. In 2014 increased 
ROA to $1.99 \%$ which means has exceeded the specified standards Bank of Indonesia.

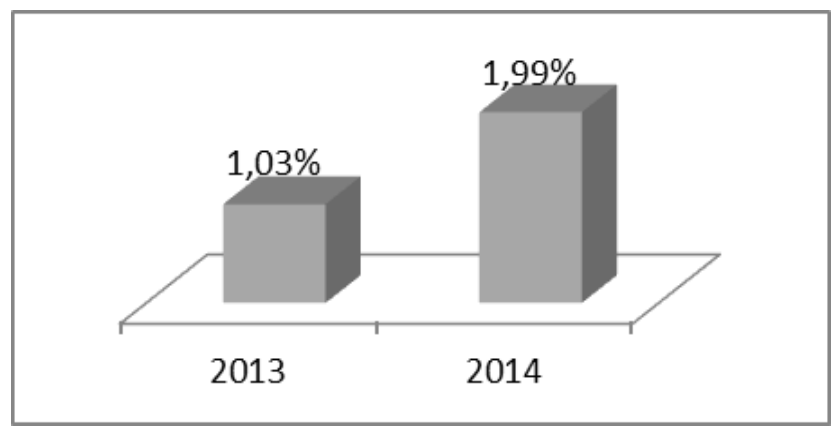

Source: Annual Report Islamic Panin Bank (data processed)

Figure 12. ROA The Islamic Panin Bank

Risk Profile and GCG

An assessment of the soundness risk-based sharia banks (RBBR) of Islamic Panin Bank was not complete if not considered the risk factor profiles and GCG. Like other banks, Islamic Panin Bank also reported the results of the selfassessment of risk factors and GCG. Now the result is the following.

Table 6

Composite Rating Risk Profile and GCG

\begin{tabular}{cccc}
\hline \multirow{2}{*}{ The Year } & $\begin{array}{c}\text { Composite Rating Risk } \\
\text { Profile }\end{array}$ & The Value & Rated \\
\hline \multirow{2}{*}{2013} & Low to Moderate & 1.35 & $\begin{array}{c}\text { Gery } \\
\text { Good }\end{array}$ \\
& Low to Moderate & 1.4 & Very \\
& & & Good
\end{tabular}

Source: Islamic Panin Bank Annual Report (data processed)

Based on the table above, it is seen that the Composite Rating Risk Profiles of Islamic Panin Bank has Low to Moderate. This means that between 2013 and 2014 the potential losses was faced by the bank from the risks inherent composites are classified as low and the quality of the implementation of risk management in a composite of adequate. Although there is a minor weakness, but it can be addressed to the attention of the management and not ignore it. Assessment of factors GCG (Good Corporate Governance) on the Islamic Panin Bank 
The Go-Public Policy and Its Impact to the Indonesian Islamic Banking Soundness Aini Masruroh, Hasbi Siraj

also shows that the bank management has been doing the implementation of GCG with very good in 2013 and 2014. This means that in general when there is a weakness in the implementation of GCG, then it does not mean significant and can be solved by the bank management.

In addition, Islamic Panin Bank also recorded the total assets that reached Rp6.2 trillion at the end of the year 2014. The growth was very significant even touching the number of Rp2.15 trillion or equivalent with 53.08\% compared to the total assets at the end of 2013 worth Rp.4.05 trillion.

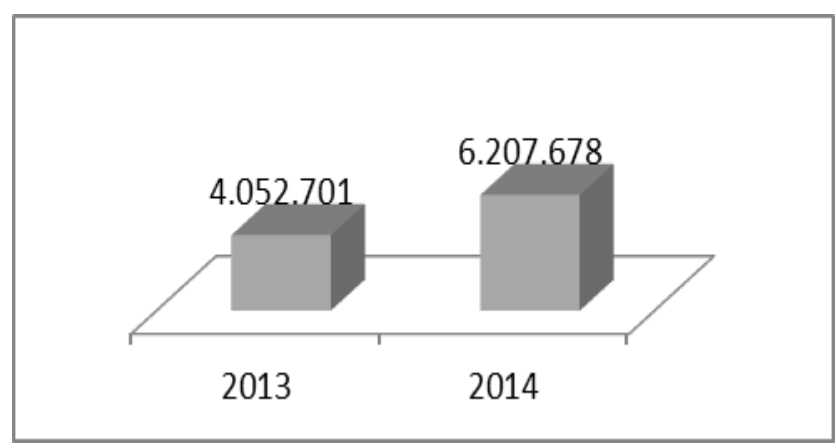

Source: Annual Report Islamic Panin Bank (data processed)

Figure 13. Total assets of Islamic Panin Bank

Based on the factors of capital, rating risk profile and GCG above, it seen that improvement of Islamic Panin Bank performance from 2013 to 2014. This period was the transition period of Islamic Panin Bank from private company to public company (Go-Public). However, it needs further analysis to answer whether GoPublic policy that has taken by the management of Islamic Panin Bank has influenced the soundness of the financial objectives.

Test analysis varies Paired-sample t test

The input that has been used to test the different paired-sample $t$ test in this research is a financial ratio that represents the factor earning and capital which ROA, NOM and CAR. The period is taken to be made as samples in this test is one year before the Go-Public and one year after Go-Public using the data derived from the quarterly financial report issued by Islamic Panin Bank. Now ROA data, NOM and CAR is as follows. 
Table 7

Financial ratio of Islamic Panin Bank Pre Go-Public and Post GoPublic

\begin{tabular}{ccccc}
\hline $\begin{array}{c}\text { The status of the } \\
\text { Bank }\end{array}$ & $\begin{array}{c}\text { The } \\
\text { Period }\end{array}$ & NOM (\%) & ROA (\%) & CAR (\%) \\
\hline \multirow{2}{*}{ Pre Go-Public } & Jun-13 & 6.15 & 2.34 & 23.11 \\
& Sep-13 & 4.97 & 2,18 & 19.75 \\
& Des-13 & 4.26 & 1.03 & 20.83 \\
& Mar-14 & 4.1 & 1.45 & 31.15 \\
& Jun-14 & 5.5 & 1.64 & 25.52 \\
Post- Go-Public & Sep-14 & 5.59 & 1.82 & 26.16 \\
& Des-14 & 5.88 & 1.99 & 25.69 \\
\hline
\end{tabular}

Source: Quarterly Report Islamic Panin Bank (data processed)

It is seen that in Table 8, the ROA variable t-test is 0.724 . It is obtained ttable on the level of the significance $\alpha=0.05$ for data on this research of 2,776 . So t-test $\operatorname{ROA}(0,724)<\mathrm{t}$-table $(2,776)$ and the significance is $0,724>0.05$ so $\mathrm{H}_{0}$ is received, this means there is no difference between the average ratio ROA between pre Go-Public and post Go-Public.

On the other hand, there is no difference between the average financial performance that voiced between one year before Go-Public and one year after Go-Public in NOM variable, whereas NOM variable t-test is 0.224 . It has obtained t-table of 2.776 on the level of the significance $\alpha=0.05$. So NOM t-test is $(0,224)<\mathrm{t}$-table $(2,776)$ and the significance of $0,837>0.05$ so $\mathrm{H}_{0}$ is received.

In the CAR variable, there is a different result. It is seen in the table 4.8. CAR variable t-test is -5.325 . It has obtained t 2.776 table at the level of the significance $\alpha=0.05$ so CAR t-test $(5.325)>(2.776)$ and the significance $0.013<0.05$ so $\mathrm{H}_{0}$ is rejected. This means that there are differences in the average CAR ratio between pre Go-Public and post Go-Public. 
The Go-Public Policy and Its Impact to the Indonesian Islamic Banking Soundness Aini Masruroh, Hasbi Siraj

The table 4.8

The output of ROA, NOM and CAR using SPSS 22

\begin{tabular}{cccc}
\hline The variables & T-test & T table & The Significance \\
\hline ROA & 0.724 & 2.776 & 0.521 \\
NOM & 0.224 & 2.776 & 0.837 \\
CAR & -5.325 & 2.776 & 0.013 \\
\hline
\end{tabular}

Source: SPSS Output (data processed)

If it is seen at first glance, the development of Islamic Panin Bank is very significant. It is started from the various existing indicator on the factor earning, capital to the risk factor profile, the implementation of Good Corporate Governance, and indicators in other financial reports, the fact that it has seen in different result.

Based on the results that obtained from the average of Islamic Panin Bank paired sample t-test, there is only difference CAR average ratio that represents the factor capital. It means that the post Go-Public capital owned by Islamic Panin Bank experiencing the changes. It is a normal consequence of Go-Public policy because it is geared toward the company to get an additional capital from the societies (public). Furthermore, Go-Public policy has not shown the significant changes toward earning factor that represented by the ratio ROA and NOM. However, Islamic Panin Bank post Go-Public has experienced many changes in many things in order to make the vision of his mission.

\section{CONCLUSION}

Based on the research, in general, the condition of the Islamic Panin Bank financial soundness of pre Go-Public shows fluctuations from the various factors that are examined. However, the fluctuations still show a positive trend so post GoPublic. The condition of the Islamic Panin Bank financial soundness shows a positive trend. Even some improvement financial indicator occurs so significant, the results from the advanced tests related to Go-Public policy taken by Islamic Panin Bank that shows Go-Public policy that has the factor capital influenced. Hence, the policy does not have the influence of the factor earning. 


\section{REFERENCES}

Fitri, Y.E .et al, 2012. Analisis Tingkat Kesehatan Bank dengan Sistem Risk Based Bank Rating (RBBR): Aplikasinya Pada Bank Bengkulu (Analysis of the soundness of the Bank with the system Risk-Based Bank Rating (RBBR): Application on the Bank of Bengkulu). Jurnal Ilmiah Manajemen Vol. 13 (2), October 2012.

Hadi, N. (2013). Pasar Modal : Acuan Teoritis dan Praktis Investasi di Instrumen Keuangan Pasar Modal (Capital Market: theoretical and practical reference for Investment in the Capital Market financial instruments). Yogyakarta: Graha Ilmu.

Hejazziey, D. (2014). Perbankan Syariah dalam Teori dan Praktik (Islamic Banking in Theory and Practice). Yogyakarta: Deepublish.

Ibadil, M.M. (2013). Analisis Pengaruh Risiko, Tingkat Efisiensi dan Good Corporate Governance Terhadap Tingkat Kinerja Keuangan Perbankan (Pendekatan Beberapa Komponen Metode Risk-based Bank Rating SEBI 13/24/DPNP/2011) (The analysis of risk level, efficiency, and Good Corporate Governance to banks financial performance level (some components of the method of Risk-based Bank Rating SEBI 13/24/DPNP/ 2011 approach). (Unpublished Thesis). Semarang: Universitas Diponegoro

Ihsan, D.N. (2013). Analisis Laporan Keuangan Perbankan Syariah. (The Analysis of Islamic Banking Financial Reports). Tangerang: UIN Jakarta Press

Lestari, S.I. (2011). Pengaruh Initial Public Offering (IPO) terhadap Kinerja Keuangan Pada PT Bank Jawa Barat dan Banten Periode 2009-2010 (The influence of Initial Public Offering (IPO) against the financial performance on PT Bank West Java and Banten period 2009-2010). (Bachelor Thesis). Bogor: Bogor Agriculture Institute (IPB).

Martalena \& M. Malinda. (2013). Pengantar Pasar Modal (Introduction to the Capital Market). Yogyakarta: ANDI Publisher

Nasarudin, M.I. (2011). Aspek Hukum Pasar Modal Indonesia (The Indonesian Capital Market Legal Aspects). Jakarta: Kencana 
The Go-Public Policy and Its Impact to the Indonesian Islamic Banking Soundness

Aini Masruroh, Hasbi Siraj

Setyawan, A.W.P. (2012). Pengaruh Komponen Risk Based Bank Rating Terhadap Harga Saham Perusahaan Perbankan yang Go Public di Bursa Efek Indonesia (BEI) Tahun 2008 - 2011 (The influence of the components of the Risk-Based Bank Rating against the company share price Go-Public banks in Indonesia Stock Exchange (BEI) 2008 - 2011). (Unpublished Bachelor Thesis). Semarang: Universitas Diponegoro.

Tanjung, H. \& A. Devi. (2013). Metode Penelitian Ekonomi Islam (Islamic Economics Research Method). Jakarta: Gramata Publishing

Widyaningrum, H.A.. et al. (2014). Analisis Tingkat Kesehatan Bank dengan Menggunakan Metode Risk Based Bank Rating (RBBR) (Studi Kasus pada Bank yang terdaftar di Bursa Efek Indonesia dalam IHSG Sub Sektor Perbankan tahun 2012) (Analysis of the soundness of the Bank by using the methods of Risk-Based Bank Rating (RBBR) (Case Study on the Bank registered in Indonesia Stock Exchange in The Jakarta Composite Index Banking Sub-Sector 2012)). Jurnal Administrasi dan Bisnis (JAB), Vol. 9 (2), April 2014. 